\title{
Service-learning as a Strategy to Promote Global Citizenship in Indonesia
}

\section{Yusuf Faisal Ali 1,* (D), and Yayuk Hidayah 2,}

1 Department of Pancasila and Civic Education, STKIP Pasundan, 40512, Cimahi, West Java Province, Indonesia

2 Department of Primary Teacher Education, Faculty of Teacher Training and Education,

Universitas Ahmad Dahlan, 55166, Yogyakarta, Indonesia

* Corresponding Author: yayuk.hidayah@pgsd.uad.ac.id

\section{ARTICLE INFO}

Publication Info:

Research Article

How to cite:

Ali, Y. F., E Hidayah, Y. (2021).

Service-learning as a Strategy to

Promote Global Citizenship in

Indonesia. Society, 9(1), 124-139.

DOI: 10.33019/society.v9i1.145

Copyright () 2021. Owned by Author(s), published by Society

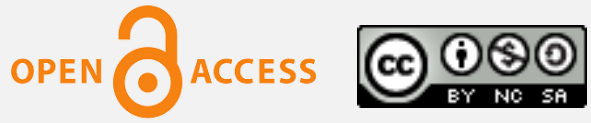

This is an open-access article.

License: Attribution-

NonCommercial-ShareAlike

(CC BY-NC-SA)

Received: January 30, 2020;

Accepted: April 10, 2020;

Published: June 25, 2021;

\begin{abstract}
The problem behind this research is service-learning usefulness as a strategy to promote global citizenship at universities in Indonesia. The methodology used in this research is a qualitative type of phenomenology. The research subjects were students involved in the Student Executive Board or Badan Eksekutif Mahasiswa (BEM) organization from eight different campuses in the Special Region of Yogyakarta or Daerah Istimewa Yogyakarta (DIY). The research results show two findings, 1) service-learning in student organizations can promote global citizenship values, and 2) service-learning in student organizations can improve industrial skills. Thus, this study concluded that student organizations in higher education could be a place to promote global citizenship and improve industrial revolution 4.0 skills among students. Therefore, the recommendation in this study is for further researchers to research by emphasizing learning outcomes that focus on the level of numbers and readiness to face the industrial revolution, which includes the ability to adopt values and nature as Indonesian people and as citizens of the world.
\end{abstract}

Keywords: BEM; Global Citizenship; Higher Education; Industrial Revolution; Service-learning

Copyright (C 2021. Owned by Author(s), published by Society. This is an open-access article under the CC-BY-NC-SA license. 


\section{Introduction}

This research is a reflection of the Global Citizenship discourse, which is gaining popularity in Indonesia. Lately, the professional development of industrial revolution 4.0 has become phenomenal in parts of the world. One of the criticisms of the third industrial revolution is its failure to solve the problems of modern society (Morrar, 2014). The nature of the industrial revolution, thick with nuances of technological novelty, has triggered concerns about the relationship compatibility between technological and social innovation. Industrial development underwent a revolution through communication and collaboration systems (Umachandran et al., 2018). Research in India on anxiety due to job loss in the era of the industrial revolution 4.0 resulted in a finding that the threat of job loss cannot be avoided but can be handled with retraining that produces skills following the interests of the industrial revolution 4.0 (Mehta \& Awasthi, 2019).

Meanwhile, a study in Germany studied the economic, ecological, and social implications of Industrial of Internet Things (IIoT) involving 46 manufacturing companies. The results, in a finding that to qualify, the application of IIoT requires three dimensions of handling, namely the integration of technical, information, and public context (Kiel et al., 2017). Furthermore, the findings of these studies indicate the problems in the industrial revolution consensus, so efforts are needed in dealing with these problems.

Higher education is expected to take advantage of the potential of the industrial revolution 4.0. Universities are now required to idealize the learning environment and learning outcomes and respond to the global needs and skills of the industrial revolution. Based on the quote in the article "Creating the New American College", sued universities in the United States to reconsider their educational principles in educating students by prioritizing responsibilities as good citizens, rather than emphasizing careers alone (Bringle \& Hatcher, 1996).

In the face of concerns about industrial revolution 4.0, service-learning is again considered an alternative in higher education to identify and solve industrial revolution 4.0 problems. The service-learning framework combines student knowledge with experience in society (Barbara Jacoby and Associates, 1996). Service-learning is now developing in the United States and emerging in South America, Asia, Europe and is applied at all formal and informal education levels (Gregorova et al., 2016).

In 2005, Matej Bel University in Banská Bystrica, Slovakia, held a Real Work Lecture or Kuliah Kerja Nyata (KKN) strategy in the 2013-2014 and 2014-2015 academic years to implement service-learning. This study found that KKN can positively impact the development of student competencies (Gregorova et al., 2016). Meanwhile, research on students at California State University who participated in KKN resulted in a finding that students got academic experiences that could increase their participation in community life (Herrera, 2017). Based on this description, the implementation of service-learning in various countries is manifested in KKN.

Service-learning in higher education, an alternative in promoting global citizenship and improving industrial revolution skills, emphasizes the function of higher education in supplying graduates who are ready to compete in the industrial revolution era and are ready to promote global citizenship. However, the space for higher education in global citizenship education has a less than adequate theoretical basis and is sometimes ambiguous. Therefore, the study should develop global citizenship thinking and professionalism (Lilley et al., 2016). Research findings that conceptually design global citizenship learning generate an idea that reflexivity, relationality, criticality, and social-imaginary are global citizenship mindsets (Lilley et al., 2014).

Copyright (C 2021. Owned by Author(s), published by Society. This is an open-access article under the CC-BY-NC-SA license. 
The study results that investigated the understanding of global citizenship in students in Australia and the European Union during 2013-2014 resulted in the findings that students' understanding of global citizenship was related to philosophical, psychological, and moral thinking habits (Robinson \& Levac, 2017). Furthermore, Noh (2018) emphasizes the role of developing non-governmental organizations in the scope of global citizenship. In Indonesia, one of the service-learning strategies is manifested in the implementation of KKN. KKN is a manifestation of the Tri Dharma of Higher Education (Teaching, Research, and Community Service) (Tim Penyusun Buku Pedoman KKN PPM, 2007).

This study investigates the form of service-learning manifested in the Student Executive Board or Badan Eksekutif Mahasiswa (BEM) student organization in promoting global citizenship. As introduced by John Dewey, service-learning is field learning to train students to know the real world in society.

This study aims to provide an overview of service-learning as learning that can promote global citizenship discourse. Based on previous research, the researcher found one research gap related to other functions of student organizations as a service-learning strategy in Indonesia that previous studies have not discussed.

Practically, this research is expected to contribute ideas about service-learning in student organizations to promote global citizenship. In addition, theoretically, it is expected to become the basis for further research which is interested in similar research.

\section{Research Methodology}

The approach used in this research is a qualitative approach with the type of phenomenology. The analysis uses phenomenological qualitative to capture phenomena comprehensively. Phenomenological studies aim to find answers about the meaning of a phenomenon (Denzin \& Yvonna, 1988). This phenomenological qualitative method is carried out in a natural situation, so there is no limit in interpreting the phenomenon. In this case, Creswell (2009) asserts that the phenomenological approach delays all judgments about attitudes or epoche. Thus, Epoche becomes one of the components for researchers in compiling and organizing initial assumptions about the phenomenon to understand what the respondents said.

The subjects in this study were 24 students involved in BEM at eight (8) different campuses in the Special Region of Yogyakarta, Indonesia. The selection of research subjects or informants used a purposive sampling method, namely taking samples based on certain objectives and considerations. The considerations in selecting the sample in the study are 1) Active students, 2) Registered as a member of the BEM, 3) Active as a member of the BEM for more than three months.

The research subjects came from different majors at the BEM on eight (8) different campuses in the Special Region of Yogyakarta, Indonesia. The eigth campuses are Universitas Gadjah Mada, Universitas Negeri Yogyakarta, Universitas Sanata Dharma, Universitas Islam Negeri Sunan Kalijaga, Universitas Atma Jaya Yogyakarta, Universitas Ahamad Dahlan, Universitas Islam Indonesia, and Universitas Kristen Duta Wacana.

Copyright (C 2021. Owned by Author(s), published by Society. This is an open-access article under the CC-BY-NC-SA license. 


\section{Service-learning as a Strategy to Promote Global Citizenship in Indonesia}

\section{Table 1. Distribution of Research Subjects}

\begin{tabular}{|l|}
\hline \multicolumn{1}{l}{ Information } \\
\hline Gender \\
\hline Male \\
\hline Female \\
\hline Age \\
\hline 18-20 \\
\hline $21-24$ \\
\hline \\
\hline Education \\
\hline S1 \\
\hline Department \\
\hline Management \\
\hline Psychology \\
\hline English Language education \\
\hline Islamic education \\
\hline Chemical Engineering \\
\hline Biology \\
\hline Architecture \\
\hline Educational Guidance and Counseling \\
\hline Dance Education \\
\hline Communication \\
\hline Public Administration \\
\hline Industrial Engineering \\
\hline Total \\
\hline
\end{tabular}

\begin{tabular}{|c|}
\hline Total \\
\hline 15 \\
\hline 9 \\
\hline \\
\hline 16 \\
\hline 8 \\
\hline \\
\hline 24 \\
\hline 3 \\
\hline 1 \\
\hline 2 \\
\hline 1 \\
\hline 1 \\
\hline 2 \\
\hline 1 \\
\hline 2 \\
\hline 7 \\
\hline 2 \\
\hline 1 \\
\hline 1 \\
\hline 24 \\
\hline
\end{tabular}

Source: Research Data (2019)

Data was collected through structured interviews with different locations according to the agreement between the researcher and the informants. The interview lasted for 30-40 minutes and covered the following questions:

1) Why did you join BEM?

2) How do you work in BEM?

3) How can you survive in BEM?

Furthermore, data collection is done through observation. Observation is an activity to record symptoms in the field for scientific purposes (Morris, 1973). Observations in this study were non-participatory observations that took place from May 2019 to September 2019, by conducting investigations and observations on student activities before BEM activities took place, during BEM activities, and after BEM activities ended.

The last data collection technique is documentation. This documentation technique is carried out by collecting information on research issues from various library sources, such as 
books, journal articles, magazines, research reports, work programs of each BEM, and other relevant document sources.

The data obtained were analyzed using Miles and Huberman's data analysis principles, including data collection, data reduction, data presentation, and concluding (Miles et al., 2014).

\section{Results and Discussion}

Based on data processing, this study found two data related to service-learning in universities, namely service-learning as a strategy to promote global citizenship and servicelearning as a strategy to improve industrial revolution skills in students. From the two data, this study seeks to dissect and analyze further as follows:

\subsection{Service-learning as a Strategy to Promote Global Citizenship}

The analysis results show that the majority of students involved in BEM have the motivation to take BEM. In the discourse of global citizenship, the nation's economic, social, and cultural interests demand that educational outputs have good knowledge of global issues and skills to work in an international context (Lunn, 2008).

Regarding the promotion of global citizenship, the findings of this study are supported by the findings of a comparative analysis of three important United Nations documents in the last five years. It suggests the importance of reviewing constructive values, assumptions, and strategies to answer fundamental questions about the nature, goals, and educational applications for various contexts (VanderDussen, 2017).

There are several assumptions in interpreting global citizenship. In this context, this research can derive an idea that global citizenship is those who have a critical understanding of participation, share the value of responsibility, respect differences, and are committed to action (Noh, 2018). On the other hand, another assumption says that global citizenship can be interpreted as a form of mastery of the world economy. Still, there is also an assumption that says global citizenship is awareness in feeling problems globally.

As a comparison of assumptions about global citizenship, the results of the exploration of Chinese youth about the impact of a program on the personality and social development of Chinese youth with Chinese backgrounds show that R\&S mobilizes Chinese youth to work for the benefit of the environment, community, and themselves (Johnson et al., 2007).

The interview results with RADP on April 10, 2019, a student of the Department of Management involved in BEM at Universitas Kristen Duta Wacana, about the motivation to be involved in BEM, said that the motivation to be involved in BEM is to be active in the community. In addition, it can encourage the development of knowledge and skills.

"... one of my motivations to be involved in the BEM of Universitas Kristen Duta Wacana was that I realized that I was in a vast world, and I was in a state of ignorance. So I started to realize through this BEM".

Based on the results of these interviews, RAPD's involvement in BEM was motivated by various elements and components. The rationale is that involvement in BEM is beneficial as a strategy to promote global citizenship. Still, it turns out that many things or essences drive the intensity of RAPD involvement in BEM.

In the same case, in an interview on April 15, 2019, JR, a student of Universitas Negeri, responded that he was motivated to join BEM of Universitas Negeri Yogyakarta because he can

Copyright (C) 2021. Owned by Author(s), published by Society. This is an open-access article under the CC-BY-NC-SA license. 
be involved in BEM a larger community than in class. Moreover, at BEM, he can contribute ideas for BEM of Universitas Negeri Yogyakarta to be better.

In addition, ASPS, who was interviewed on April 25, 2019, a student of the Department of Psychology at Universitas Sanata Dharma, revealed the same thing. Being involved in the BEM of Universitas Sanata Darma is evidence that students on campus come to sit in class and be involved in activities that can positively impact the students themselves and their environment.

Based on interviews results with JR and ASPS, it can be seen that the majority of students who are involved in BEM have the motivation to be involved in the community and hope to bring change or impact on their environment by donating their thoughts at BEM. This finding indicates that through BEM, students indirectly promote themselves as global citizenship. The scope of global citizenship can include social responsibility, global competence, and global civic engagement (Morais \& Ogden, 2010). Thus, these scopes are concretized in activities at BEM.

The above phenomenon provides an understanding that the concept of global citizenship is related to individual morals in general (Cabrera, 2008). This statement is following the function of student organizations as a forum to promote global citizenship. A case study research that analyzed the impact of long-term International Learning Internship services on eight students proved that students' thinking shifted towards the conception of global citizenship, especially those related to social justice actions. Indirectly, experience in the international realm strengthens the dispositions of global citizenship, attitudes, and actions of the eight students (Larsen \& Searle, 2017).

Involvement in organizations is an opportunity for students to realize themselves as global citizenship. For example, in America, to increase the inclusion of international students, they adopt the principles of cosmopolitanism (George-Jackson, 2010). Meanwhile, in Australia, educating students on environmental conservation by basing Hawkins' definition of global citizenship shows the benefits for students in understanding social justice issues, especially those related to gender, carbon emissions, and global impacts (Boetto \& Bell, 2015).

Promoting global citizenship by referring to the ease of communication can be part of the spirit of globalism. A study of the spirit of globalism in families with young children who volunteer abroad shows the context of family volunteerism to push children towards global subjectivity. This family volunteerism reflects the neoliberal logic that forces parents to prepare their children for the future and equip them with adaptability, open-mindedness, compassion, and gratitude (Germann, 2015).

Thus, educators should pay attention to policies related to student motivation, selfregulation, and academic performance (Tye, 2014). Furthermore, the relationship between motivational factors and self-regulation with academic performance are two assessment policies (Kickert et al., 2019).

The idea of global citizenship education is a response from UNESCO regarding the issues of human rights violations, social inequality, and the increasingly distant world condition (UNESCO, n.d.). Thus, the values of global citizenship become valuable and embedded in every individual, especially in the current era of the industrial revolution.

School curricula have been recommended to respond to various variants of global citizenship (Bates, 2012). The need to become global citizenship as a responsive effort to the existence of globalization. Globalization affects many aspects of life and requires humans to adopt an international perspective (Xin et al., 2016). Through student organizations, global citizenship efforts are crystallized in various activities that can encourage students to get used to the global level, such as tolerance, problem-solving, and the desire to change their surroundings.

Copyright (C) 2021. Owned by Author(s), published by Society. This is an open-access article under the CC-BY-NC-SA license. 
Globally, global inequality existence is closely related to the urgency and impact of the global economy (Gaynor, 2015). At a different level, global citizenship can be manifested through the internationalization of higher education in international services, international internships, studying abroad, and all of these provide global experiences (Aktas et al., 2016).

Student organizations (to globalize citizens) can be dedicated to the interests of higher education and the world innovatively. An analysis of phenomena related to experience and global citizenship and a conceptual framework adapted from the Value-Belief-Norm theory can be used as material to understand the role of studying abroad in maintaining global citizenship (Tarrant, 2009).

Meanwhile, in higher education, assessment is the primary learning instrument and strongly influences the student experience (Thomas et al., 2018). Student organizations become groups in manifesting student experiences and group work. In this context, students work together on a project to overcome the challenges of a challenge. They gain many benefits, including learning skills and experiences and increased motivation (Harvey et al., 2019).

More than just an academic discourse, global citizenship can maximize individual identity optimally. Citizenship is an individual identity in a politically sensitive society atmosphere. This is in line with the goal of Citizenship Education, which is to change the discourse of 'us' and 'them' into a more inclusive 'us' (Leonard, 2007).

In Morocco, the perspective on Citizenship Education in education policy reform focuses on Morocco's strategic vision of Reform 2015-2030. This perspective targets civic education for schools that develop individuals and communities, democracy and equality (Idrissi et al., 2019). The findings provide a new paradigm that student organizations are a form of service learning in Indonesian universities that can realize global citizenship values.

In Britain, the beginning of the 21st century is known as an extreme turbulence period in all levels of education. A study of educational policy and practice in England, Wales, Scotland, and Northern Ireland identified the opportunities and challenges faced by teacher education in all four countries (Bamber et al., 2016). Previous research conducted by The International Baccalaureate (IB) Program and Montessori Education as a program that promotes global citizenship values resulted in the idea that although IB has criticisms and philosophies, IB can prove its effectiveness in developing an intercultural perspective in higher education. Montessori Education develops the values of global citizenship by using its new paradigm of education to promote sensitivity and respect for children from different cultures (BrunoldConesa, 2010).

Thus, the values of global citizenship become the menu in educational institutions. It is proven that in recent years the European education system has reformed the curriculum related to global citizenship efforts because global citizenship efforts in civic education address the issue of citizenship nationally, globally, and cultural diversity (Engel, 2014)

In short, global citizenship has spread to all aspects of privacy and the non-privacy of citizens. Implementing the service-learning approach in the entrepreneurship program provides a real place to practice for students to produce experiences related to citizens directly (Desplaces et al., 2009).

On a global scale, the character of global citizenship becomes a constitutional and nonconstitutional right and obligation to be affirmed in fulfilling one's interests. The role of schools, communities, and governments in preparing global citizenship is very important because the balance between learning experiences and interactions in an international space is an ideal condition for teachers to develop perspectives about the world (Roberts, 2003). This is because global citizenship is explored as a concept for public administration at the local level that can be

Copyright (C 2021. Owned by Author(s), published by Society. This is an open-access article under the CC-BY-NC-SA license. 
used to provide insight into how to make public services more inclusive in an increasingly dynamic and diverse world (Lucio, 2009).

Thus, the idea that can be obtained is that service-learning as a strategy to promote global citizenship effectively realizes analytical thinking schemes useful for problem-solving abilities effectively and quickly. Global citizenship emphasizes skills that can find elements of complex problem solving so that to solve these problems, the collection of relevant information by students can be well organized. From the analysis conducted, it is known that promoting global citizenship cannot be separated from a necessity to have skills that are responsive to cultural changes.

\subsection{Improving Industrial Skills}

The analysis of work patterns and survival methods at BEM resulted in a finding that most students have skills that can support the skills of the industrial revolution. In line with these results, a study of higher education institutions in South Africa that is expected to promote social and economic development provides recommendations that service-learning can contribute to the spirit of citizenship and social responsibility (Dorasamy \& Pillay, 2010).

In addition, through student organizations, service-learning can also teach in technological literacy, the ability to innovate, the moral foundation, and the ability to communicate effectively. This is because social work is increasingly developing an international perspective by acquiring human rights literacy, empathy, responsibility and transforming it into a form of global leadership (Hawkins \& Knox, 2014).

Responding to several studies that review the challenges and obstacles above, developing countries and UNESCO use the ideology of "learning city" as a strategy to promote lifetime learning (Yang, 2012). Research on the position of Developmental Education (DE) or Global Education (GE) in Estonian formal education provides a wealth of information on the similarities and differences in the status, practice, and support for ED in the education sector in various states, such as Indonesia, the European Union, Estonia, and other new member countries (Helin, 2009).

Improving industrial skills through student organizations that support global knowledge can facilitate students to have social sensitivity that is beneficial for their skills in the industrial sector. Even though it is full of problems, the idea of global citizenship can be accepted even if it uses other terms to describe the ideal output of global citizenship. However, existing knowledge, skills, and attitudes are closely related to the epistemology and ontology of moral cosmopolitanism and transformation (Lilley et al., 2016).

An interview on May 2, 2019, with IAP, an informant member of the BEM from the Department of Management, Universitas Islam Indonesia in Yogyakarta, responded about activity at the BEM at Universitas Islam Indonesia. IAP said that working in BEM is collaborating, namely collaboration between members. In this collaboration, of course, there are values of responsibility and leadership. Because all members already have their respective duties.

The same thing was conveyed by LA when interviewed on May 16, 2019, a student of the Department of Islamic Education who is active at the BEM at Universitas Ahmad Dahlan. He learned about skills that were beneficial to him during his participation and being a part of BEM.

Based on the results of the two interviews, it can be seen that in the BEM environment, they can work and move according to their respective goals. If observed, there are several values and knowledge obtained, including 1) they already have a predetermined goal; 2) they get their

Copyright (C) 2021. Owned by Author(s), published by Society. This is an open-access article under the CC-BY-NC-SA license. 
respective division of tasks during their activities at BEM; 3) the existence of the principle of mutual help during their activities in BEM; 4) there is a mutual relationship between BEM members, and 5) they have good coordination among BEM members.

Through BEM, industrial revolution skills that include responsibility and innovation can be realized in student activity units. Students involved in BEM admit that during their activities in BEM, these values are manifested unwritten but manifest in the form of solid cooperation.

On the other hand, community welfare is a function of several factors that work together to promote an optimal quality of life (Merriam \& Kee, 2014). Industrial revolution skills that include the above values become a form of civic literacy. Civic literacy education is often seen as a medium to promote citizenship, responsibility, equality, and participation (Arthur, 2012).

Today, there is less attention to the dimensions of social skills (Grzyb, 1990), so the participatory approach is expected to provide an impetus for generating critical thinking about the reality that occurs outside of school (Wasner, 2016). Ethnographic studies investigating why workers sometimes choose boring (ordinary) jobs lead to the idea that workers view boring work as a safe way to retreat from a situation in which responsibility is paramount (Molstad, 1986).

In the same case, the following interview results provide information that service-learning through student organizations contributes to realizing industrial revolution skills. In this case, SAS, an Universitas Atma Jaya Yogyakarta student who was also part of the BEM when interviewed on May 28, 2019, said that the way to survive in the BEM is to give yourself confidence and responsibilities which have been enrolled. In addition, effective communication can also help in efforts to survive at BEM of Universitas Atma Jaya Yogyakarta.

The same thing was stated by OTK when interviewed on July 2,2019, as a student of the Department of Communication at Universitas Gadjah Mada with the response that when talking about survival, it would certainly be related to self-concept regarding consistency. OTK emphasized that staying at BEM of Universitas Gadjah Mada, besides being a form of consistency and responsibility, also received useful lessons. OTK feels that they can learn about technology to expand useful content and practice problem-solving at BEM of Universitas Gadjah Mada.

Based on the interviews with SAS and OTK, it can be concluded that concerning how to survive, BEM has several dimensions that can strengthen their defense, including task dimensions, group dimensions, role dimensions, and goal dimensions. Some of these dimensions will eventually create works that can color and give strength to unity in BEM. How to defend yourself in BEM can identify "dangers" that come from inside and outside BEM. This will then be able to regulate and determine the attitude of BEM members to the existing "danger". With this, loyalty to BEM will emerge.

The industrial revolution has intensified globalization and can positively impact the economic and social sectors (Schäfer, 2018). One of the service-learning efforts through student organizations in improving industrial revolution skills is technical skills. In a neoliberal individualistic society, the experience of communal life remains important for human life (Fixsen \& Ridge, 2018).

The development of technology raises new problems in human relations. The study results using data from 60 in-depth interviews with white students from middle and upper-class backgrounds at two higher education institutions found a finding that there are some similarities in how working students and middle-class students perceive social class (Stuber, 2006). Lack of communication and lack of interaction can hinder the process of mastering one's

Copyright (C 2021. Owned by Author(s), published by Society. This is an open-access article under the CC-BY-NC-SA license. 
skills. Many adolescents experience social rejection and anxiety when they are not accepted by certain social groups (Evans \& Eder, 1993).

In this case, SI, an Universitas Islam Negeri Sunan Kalijaga student involved in BEM, revealed that one way to work and survive at BEM relies on technology. Communication is lacking; academic activities require an effective communication platform for members. In addition, educational learning in using technology is also in BEM.

From the analysis carried out, it can be seen that the industrial skills in this research are in the form of technological ability, moral foundation, ability to innovate, and ability to communicate effectively. As the discourse develops in higher education and industrial skills, the literacy skills of educational outputs at least include technological literacy, data literacy, language, and science. More broadly, the ability to master technology (technology literacy) is more than the ability to use computers and machines and understand the creation and development of technology and the impact of technology on society, individuals, and the environment (Bugliarello, 2000).

In this 21st century, the ability is sufficient on the ability to read and the ability to use audio-visual media, which will ultimately strengthen information literacy. Efforts to promote technological literacy need to consider the complexities, nature, and contexts that rely on technological literacy, such as its history and relationship to scientific literacy (Beaver, 1986).

Research in Luxville, a Manhattan neighborhood in New York City, led to the idea that specific factors contribute to developing a community there whose members are unexpectedly local immigrant workers (Miller, 2014). Meanwhile, a study that explores Scientific and Technological Literacy (STL) from a social-constructivist perspective suggests several criteria for evaluating a person's abilities in a technoscientific society, including simple interdisciplinary models, comparison and drawing, translation, discipline, and rationality in the decision-making process (Fourez, 1997). The skills framework in the 21st century can be seen in the following figure.

\begin{tabular}{|c|c|c|c|}
\hline $\begin{array}{l}\text { Mentioned in all } \\
\text { frameworks }\end{array}$ & $\begin{array}{l}\text { Mentioned in most } \\
\text { frameworks }\end{array}$ & $\begin{array}{l}\text { Mentioned in a few } \\
\text { frameworks }\end{array}$ & $\begin{array}{l}\text { Mentioned only in } \\
\text { one framework }\end{array}$ \\
\hline $\begin{array}{l}\text { - Communication } \\
\text { - Collaboration } \\
\text { - ICT literacy } \\
\text { - Social and/or } \\
\text { cultural skills }\end{array}$ & $\begin{array}{ll}\text { - } & \text { Creativity } \\
\text { - } & \text { Critical } \\
\text { thinking } \\
\text { - } & \text { Problem } \\
& \text { solving } \\
\text { - } & \text { Develop } \\
& \text { quality } \\
& \text { products/ } \\
& \text { productivity }\end{array}$ & $\begin{array}{l}\text { - Learning to } \\
\text { learn } \\
\text { - Self-direction } \\
\text { Planning } \\
\text { - } \begin{array}{l}\text { Flexibility, and } \\
\text { adaptability }\end{array}\end{array}$ & $\begin{array}{l}\text { - } \quad \text { Risk taking } \\
\text { - Manage and solve } \\
\text { conflicts } \\
\text { - Sense of initiative and } \\
\text { entrepreneurship }\end{array}$ \\
\hline
\end{tabular}

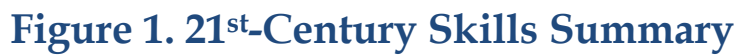

Source: Romero et al., (2014)

The $21^{\text {st }}$-century skills framework can be a reference in mapping the skills of the industrial revolution. In Germany, the industrial revolution is defined as "the application of the generic concept of cyber-physical systems (CPS) to industrial production systems (cyber-physical production systems)". This is similar to North America, although its application emphasizes industry only (Drath \& Horch, 2014).

Industry 4.0 skills for students are capital in facing the realities of the world. The close relationship between the global economy, ecosystems and political networks has required 
students to learn to communicate, collaborate, and solve problems with people worldwide (Saavedra \& Opfer, 2012). In addition, negotiation skills that include defining, expressing rights, and showing empathy are unique in facing the industrial era (Austin, 2016).

The analysis results of this phenomenon provide a lesson that improving industrial skills is considered too late if it must be enlivened in the 21st century. In truth, there is a gap in every opportunity to advance the capabilities of human resources to explore the productivity of this industrial era. In New Zealand, the notion of "being" has been reflected in the social and political aspects of the country's independence (Mutch, 2002). In Indonesia's context, a new version of global citizenship is important in anticipating concerns about artificial intelligence. In this case, technology education is important for mastering the future (Lauda, 1994). There are many forms of communication technology and its potential as a new approach in teaching and learning activities (Turner \& Katic, 2009).

In the end, this research provides an affirmation that service-learning is useful in improving industrial skills. Through service-learning, the discovery of creative and innovative thinking can be encouraged. In the context of student life, exploring problems in social life through BEM can be used as a source of learning. Furthermore, this research shows that collaboration in BEM can encourage students to reflect on the world and themselves and plan conceptual plans that can benefit them in improving their industrial skills.

\section{Conclusion}

Based on the results of data analysis, this study resulted in two conclusions: first, servicelearning in student organizations in higher education is one strategy to promote global citizenship and create a mindset oriented to global citizenship values to bring change, be active in the community, and cooperate with others. Service-learning in student organizations in universities is a strategy in promoting global citizenship, which is carried out by strengthening the elements as humans in their activities. The data analysis supports a statement that the pattern of work and activities in BEM formed in a team/group is more effective in achieving goals when compared to work carried out individually.

Second, service-learning in student organizations at universities is a strategy to improve industrial revolution skills, including technological literacy, problem-solving, innovation, and providing a moral foundation for students' responsibility and leadership. Based on the support of the results of data analysis, service-learning in student organizations in higher education is a strategy in improving the skills of the industrial revolution based on the arguments and principles of $21^{\text {st }}$-century education developed by the World Economic Forum (WEF) to survive in the present and the future. The results of the data analysis that support the second conclusion in improving the skills of the industrial revolution are divided into three groups according to the WEF provisions, including basic literacy, competence, and character education within the framework of student organizations in higher education.

\section{Acknowledgment}

The researchers would like to thank Universitas Gadjah Mada, Universitas Negeri Yogyakarta, Universitas Sanata Dharma, Universitas Islam Negeri Sunan Kalijaga, Universitas Atma Jaya Yogyakarta, Universitas Ahamad Dahlan, Universitas Islam Indonesia, and Universitas Kristen Duta Wacana. Thank you to all Student Executive Board or Badan Eksekutif Mahasiswa (BEM) members who were willing to be interviewed.

Copyright (C) 2021. Owned by Author(s), published by Society. This is an open-access article under the CC-BY-NC-SA license. 


\section{Declaration of Conflicting Interests}

The authors have declared no potential conflicts of interest concerning the study, authorship, and/or publication of this article.

\section{References}

Aktas, F., Pitts, K., Richards, J. C., \& Silova, I. (2016). Institutionalizing Global Citizenship. Journal of Studies in International Education, 21(1), 65-80. https:// doi.org/10.1177/1028315316669815

Arthur, C. (2012). Financial Literacy Education for Citizens: What Kind of Responsibility, Equality, and Engagement? Citizenship, Social and Economics Education, 11(3), 163-176. https:/ / doi.org/10.2304/csee.2012.11.3.163

Austin S. M. (2016). Making MY Grade. Journal of Contemporary Ethnography, 45(5), 553-579. https:// doi.org/10.1177/0891241615587378

Bamber, P., Bullivant, A., Glover, A., King, B., \& McCann, G. (2016). A comparative review of policy and practice for education for sustainable development/education for global citizenship (ESD/GC) in teacher education across the four nations of the UK. Management in Education, 30(3), 112-120. https:/ / doi.org/10.1177/0892020616653179

Barbara Jacoby and Associates. (1996). Service-Learning in Higher Education: Concepts and Practices (1st ed.). San Francisco, California: Jossey-Bass.

Bates, R. (2012). Is global citizenship possible, and can international schools provide it? Journal of Research in International Education, 11(3), 262-274. https:// doi.org/10.1177/1475240912461884

Beaver, D. D. (1986). Technological Literacy, Old and New. Bulletin of Science, Technology $\mathcal{E}$ Society, 6(3), 229-234. https:/ / doi.org/10.1177/027046768600600314

Boetto, H., \& Bell, K. (2015). Environmental sustainability in social work education: An online initiative to encourage global citizenship. International Social Work, 58(3), 448-462. https:/ / doi.org/10.1177/0020872815570073

Bringle, R. G., \& Hatcher, J. A. (1996). Implementing Service Learning in Higher Education. The Journal of Higher Education, 67(2), 221. https:/ / doi.org/10.2307/2943981

Brunold-Conesa, C. (2010). International education: The International Baccalaureate, Montessori and global citizenship. Journal of Research in International Education, 9(3), 259-272. https:/ / doi.org/10.1177/1475240910382992

Bugliarello, G. (2000). Reflections on Technological Literacy. Bulletin of Science, Technology $\mathcal{E}$ Society, 20(2), 83-89. https:/ / doi.org/10.1177/027046760002000201

Cabrera, L. (2008). Global Citizenship as the Completion of Cosmopolitanism. Journal of International Political Theory, 4(1), 84-104. https:/ / doi.org/10.3366/e1755088208000104

Creswell, J. W. (2009). Research Design: Qualitative, Quantitative, and Mixed Methods Approaches. Newbury Park, California: Sage Publications.

Denzin, N. K. \& Yvonna S. L. (1988). Straegies of Qualitative Inquiry. Thousand Oaks, California: Sage Publications.

Desplaces, D. E., Wergeles, F., \& McGuigan, P. (2009). Economic Gardening through Entrepreneurship Education. Industry and Higher Education, 23(6), 473-484. https:/ / doi.org/10.5367/000000009790156436

Dorasamy, N., \& Pillay, S. (2010). Advocating Service Learning for Developing Citizenship in University Students in South Africa. Industry and Higher Education, 24(4), 287-296. https:/ / doi.org/10.5367/000000010792609736 
Drath, R., \& Horch, A. (2014). Industrie 4.0: Hit or Hype? [Industry Forum]. IEEE Industrial Electronics Magazine, 8(2), 56-58. https:/ / doi.org/10.1109/mie.2014.2312079

Engel, L. C. (2014). Global citizenship and national (re)formations: Analysis of citizenship education reform in Spain. Education, Citizenship and Social Justice, 9(3), 239-254. https:/ / doi.org/10.1177/1746197914545927

Evans, C., \& Eder, D. (1993). “No Exit.” Jour nal of Contemporary Ethnography, 22(2), 139-170. https:// doi.org/10.1177/089124193022002001

Fixsen, A., \& Ridge, D. (2018). Shades of Communitas: A Study of Soft Skills Programs. Journal of Contemporary Ethnography, 48(4), 510-537. https://doi.org/10.1177/0891241618792075

Fourez, G. (1997). Scientific and Technological Literacy as a Social Practice. Social Studies of Science, 27(6), 903-936. https:/ / doi.org/10.1177/030631297027006003

Gaynor, N. (2015). Shopping to save the world? Reclaiming global citizenship within Irish universities. Irish Journal of Sociology, 24(1), 78-101. https:// doi.org/10.7227/ijs.0003

George-Jackson, C. E. (2010). The Cosmopolitan University: The Medium toward Global Citizenship and Justice. Policy Futures in Education, 8(2), 191-200. https:/ / doi.org/10.2304/pfie.2010.8.2.191

Germann M. J. (2015). Giving Back, Doing Good, Feeling Global: The Affective Flows of Family Voluntourism. Journal of Contemporary Ethnography, 46(3), 334-360. https:// doi.org/10.1177/0891241615610382

Gregorova, A. B., Heinzova, Z., Chovancova, K. (2016). The Impact of Service-Learning on Students' Key Competences. International Journal of Research on Service-Learning and Community Engagement 4(1), 367-376. Retrieved from https:/ /journals.sfu.ca/iarslce/index.php/journal/article/view/246

Grzyb, G. J. (1990). Deskilling, Decollectivization, and Diesels. Journal of Contemporary Ethnography, 19(2), 163-187. https:/ / doi.org/10.1177/089124190019002001

Harvey, H., Keen, J., Robinson, C., Roff, J., \& Gross, T. (2019). Quantitative analysis of approaches to group marking. Assessment $\mathcal{E}$ Evaluation in Higher Education, 44(8), $1133-$ 1147. https:/ / doi.org/10.1080/02602938.2019.1572069

Hawkins, C. A., \& Knox, K. (2014). Educating for international social work: Human rights leadership. International Social Work, 57(3), 248-257. https:/ / doi.org/10.1177/0020872813519462

Helin, J. (2009). Development Education in School Curricula in Europe: Global Challenge for Estonian Schools. Citizenship, Social and Economics Education, 8(2-3), 128-143. https:/ / doi.org/10.2304/csee.2010.8.2.128

Herrera, E. (2017). The Impact of Service-Learning on Undergraduate and Graduate Students (Thesis). California State Polytechnic University. Retrieved from https:/ / scholarworks.calstate.edu/downloads/b5644t464

Idrissi, H., Engel, L. C., \& Benabderrazik, Y. (2019). New visions for citizen formation: An analysis of citizenship education policy in Morocco. Education, Citizenship and Social Justice, 16(1), 31-48. https:/ / doi.org/10.1177/1746197919886279

Johnson, L. R., Johnson-Pynn, J. S., \& Pynn, T. M. (2007). Youth Civic Engagement in China: Results From a Program Promoting Environmental Activism. Journal of Adolescent Research, 22(4), 355-386. https:/ / doi.org/10.1177/0743558407301914

Kickert, R., Meeuwisse, M., M. Stegers-Jager, K., V. Koppenol-Gonzalez, G., R. Arends, L., \& Prinzie, P. (2019). Assessment policies and academic performance within a single course: the role of motivation and self-regulation. Assessment $\mathcal{E}$ Evaluation in Higher Education, 44(8), 1177-1190. https://doi.org/10.1080/02602938.2019.1580674

Copyright (C) 2021. Owned by Author(s), published by Society. This is an open-access article under the CC-BY-NC-SA license. 
Kiel, D., Müller, J. M., Arnold, C., \& Voigt, K. I. (2017). Sustainable Industrial Value Creation: Benefits And Challenges Of Industry 4.0. International Journal of Innovation Management, 21(08), 1740015. https:/ / doi.org/10.1142/s1363919617400151

Larsen, M. A., \& Searle, M. J. (2017). International service learning and critical global citizenship: A cross-case study of a Canadian teacher education alternative practicum. Teaching and Teacher Education, 63, 196-205. https:/ / doi.org/10.1016/j.tate.2016.12.011

Lauda, D. P. (1994). Responding to the Call for Technological Literacy. NASSP Bulletin, 78(563), 44-48. https:/ / doi.org/10.1177/019263659407856308

Leonard, M. (2007). Children's Citizenship Education in Politically Sensitive Societies. Childhood, 14(4), 487-503. https:/ / doi.org/10.1177/0907568207086411

Lilley, K., Barker, M., \& Harris, N. (2014). Exploring the Process of Global Citizen Learning and the Student Mind-Set. Journal of Studies in International Education, 19(3), 225-245. https:// doi.org/10.1177/1028315314547822

Lilley, K., Barker, M., \& Harris, N. (2016). The Global Citizen Conceptualized. Journal of Studies in International Education, 21(1), 6-21. https:/ / doi.org/10.1177/1028315316637354

Lucio, J. (2009). Customers, Citizens, and Residents. Administration E Society, 41(7), 878-899. https:/ / doi.org/10.1177/0095399709344056

Lunn, J. (2008). Global Perspectives in Higher Education: Taking the Agenda Forward in the United Kingdom. Journal of Studies in International Education, 12(3), 231-254. https:/ / doi.org/10.1177/1028315307308332

Mehta, B. S., \& Awasthi, I. C. (2019). Industry 4.0 and Future of Work in India. FIIB Business Review, 8(1), 9-16. https:/ / doi.org/10.1177/2319714519830489

Merriam, S. B., \& Kee, Y. (2014). Promoting Community Wellbeing: The Case for Lifelong Learning for Older Adults. Adult Education Quarterly, 64(2), 128-144. https:// doi.org/10.1177/0741713613513633

Miles, M. B., Huberman, A. M., \& Saldana, J. (2014). Qualitative Data Analysis: A Methods Sourcebook (3rd ed.). Thousand Oaks, California: SAGE Publications, Inc.

Miller, E. A. (2014). Cultivating an Unexpected Community. Journal of Contemporary Ethnography, 44(3), 335-361. https:/ / doi.org/10.1177/0891241614530161

Molstad, C. (1986). Choosing and Coping with Boring Work. Urban Life, 15(2), 215-236. https:/ / doi.org/10.1177/089124168601500204

Morais, D. B., \& Ogden, A. C. (2010). Initial Development and Validation of the Global Citizenship Scale. Journal of Studies in International Education, 15(5), 445-466. https:/ / doi.org/10.1177/1028315310375308

Morrar, R. (2014). Innovation in Services: A Literature Review. Technology Innovation Management Review, 4(4), 6-14. https:/ / doi.org/10.22215/timreview/780

Morris, W. (1973). The American Heritage Dictionary of the English Language. Boston, USA: Houghton Mifflin Harcourt.

Mutch, C. (2002). Citizenship Education in New Zealand: Inside or outside the Curriculum? Citizenship, Social and Economics Education, 5(3), 164-179. https:/ / doi.org/10.2304/csee.2002.5.3.164

Noh, J. E. (2018). The legitimacy of development non-governmental organizations as global citizenship education providers in Korea. Education, Citizenship and Social Justice, 14(3), 241-259. https:/ / doi.org/10.1177/1746197918799972

Roberts, A. (2003). Proposing a Broadened View of Citizenship: North American Teachers" Service in Rural Costa Rican Schools. Journal of Studies in International Education, 7(3), 253-276. https:/ / doi.org/10.1177/1028315303251398

Copyright (C 2021. Owned by Author(s), published by Society. This is an open-access article under the CC-BY-NC-SA license.

https://doi.org/10.33019/society.v9i1.145

137 
Robinson, A. A., \& Levac, L. (2017). Transformative Learning in Developing as an Engaged Global Citizen. Journal of Transformative Education, 16(2), 108-129. https:// doi.org/10.1177/1541344617722634

Romero, M., Usart, M., \& Ott, M. (2014). Can Serious Games Contribute to Developing and Sustaining 21st Century Skills? Games and Culture, 10(2), 148-177. https:// doi.org/10.1177/1555412014548919

Saavedra, A. R., \& Opfer, V. D. (2012). Learning 21st-Century Skills Requires 21st-Century Teaching. Phi Delta Kappan, 94(2), 8-13. https:// doi.org/10.1177/003172171209400203

Schäfer, M. (2018). The Fourth Industrial Revolution: How the EU Can Lead It. Tạp Chí Nghiên Cứu Dân Tộc, (23). https:/ / doi.org/10.25073/0866-773x/94

Stuber, J. M. (2006). Talk of Class. Journal of Contemporary Ethnography, 35(3), 285-318. https:// doi.org/10.1177/0891241605283569

Tarrant, M. A. (2009). A Conceptual Framework for Exploring the Role of Studies Abroad in Nurturing Global Citizenship. Journal of Studies in International Education, 14(5), 433-451. https:// doi.org/10.1177/1028315309348737

Thomas, D., Moore, R., Rundle, O., Emery, S., Greaves, R., te Riele, K., \& Kowaluk, A. (2018). Elaborating a framework for communicating assessment aims in higher education. Assessment \& Evaluation in Higher Education, 44(4), 546-564. https:// doi.org/10.1080/02602938.2018.1522615

Tim Penyusun Buku Pedoman KKN PPM. (2007). Pembelajaran Pemberdayaan Masyarakat (KKN LPPM) Perguruan Tinggi Di Indonesia. Direktorat Penelitian Dan Pengabdian Kepada Masyarakat Direktorat Jenderal Pendidikan Tinggi Departemen Pendidikan Nasional, Jakarta.

Turner, K. H., \& Katic, E. K. (2009). The Influence of Technological Literacy on Students' Writing. Journal of Educational Computing Research, 41(3), 253-270. https:// doi.org/10.2190/ec.41.3.a

Tye, K. A. (2014). Global Education: A Worldwide Movement. An Update. Policy Futures in Education, 12(7), 855-871. https:// doi.org/10.2304/pfie.2014.12.7.855

Umachandran, D. K., Jurcic, I., Ferdinand-James, D., Said, M. M. T., \& Rashid, A. A. (2018). Gearing Up Education Towards Industry 4.0. International Journal of Computers $\mathcal{E}$ Technology, 17(2), 7305-7311. https:// doi.org/10.24297/ijct.v17i2.7754

UNESCO. (n.d.). Global citizenship education. Retrieved August 11, 2019, from https://en.unesco.org/themes/gced

VanderDussen T. E. (2017). Educating citizens of 'the global': Mapping textual constructs of UNESCO's global citizenship education 2012-2015. Education, Citizenship and Social Justice, 13(1), 51-64. https:/ / doi.org/10.1177/1746197917700909

Wasner, V. (2016). Critical service learning: A participatory pedagogical approach to global citizenship and international mindedness. Journal of Research in International Education, 15(3), 238-252. https:// doi.org/10.1177/1475240916669026

Xin, J. F., Accardo, A. L., Shuff, M., Cormier, M., \& Doorman, D. (2016). Integrating Global Content Into Special Education Teacher Preparation Programs. Teacher Education and Special Education: The Journal of the Teacher Education Division of the Council for Exceptional Children, 39(3), 165-175. https:/ / doi.org/10.1177/0888406416631124

Yang, J. (2012). An Overview of Building Learning Cities as a Strategy for Promoting Lifelong Learning. Journal of Adult and Continuing Education, 18(2), 97-113. https://doi.org/10.7227/jace.18.2.8 


\section{About the Authors}

1. Yusuf Faisal Ali obtained his Master's degree in Law from Universitas Islam Bandung, Indonesia, in 2004. The author is an Assistant Professor at the Department of Pancasila and Civic Education, STKIP Pasundan.

E-Mail: yusuffaisalali2016@gmail.com

2. Yayuk Hidayah obtained her Doctoral degree in Civic Education from Universitas Pendidikan Indonesia in 2020. The author is an Assistant Professor at the Department of Primary Teacher Education, Faculty of Teacher Training and Education, Universitas Ahmad Dahlan, Indonesia.

E-Mail: yayuk.hidayah@pgsd.uad.ac.id 